\title{
Protoporphyrinogen-IX Oxidase Inhibition of New Diphenyl Ethers
}

\author{
Motoo Sumida, Hitoshi KoHno, ${ }^{*}$ Kou Shouda, ${ }^{*}$ Harukazu FuKami, \\ Takaharu TANAKA, Ko WAKABAYASHI* and Peter BÖGER** \\ Institute for Biomedical Research, Research Center, Suntory, Ltd., Shimamoto-cho, \\ Mishima-gun, Osaka 618, Japan \\ * Graduate School of Agricultural Science, Tamagawa University, Tamagawa-gakuen, Machida 194, Japan \\ **Lehrstuhl für Physiologie und Biochemie der Pflanzen, Universität Konstanz, D-78434 Konstanz, Germany
}

(Received December 1, 1995 ; Accepted March 14, 1996)

\begin{abstract}
Using Scenedesmus acutus, a series of derivative compounds, namely benzoxazines, benzoquinolines and a benzoquinazoline, belonging to the diphenyl ether type compounds, were assayed for peroxidizing phytotoxic activity. All compounds decreased chlorophyll content, inhibited protoporphyrinogen-IX oxidase (EC 1.3.3.4), caused light-induced ethane evolution and inhibited growth of Scenedesmus cells, just like the so-called peroxidizing herbicides as $p$-nitrodiphenyl ethers and cyclic imides. Correlation between these phytotoxic parameters was highly significant. Our comparative data on different sets of the parameters suggest that the benzoxazines, benzoquinolines and benzoquinazoline compounds of this study are to be classified as peroxidizing herbicides affecting a crucial enzyme in the chlorophyll biosynthesis pathway and producing ethane by light-induced radicals in the cells. Many benzoxazine derivatives and benzoquinazoline exhibited a good correlation between phytotoxic parameters and herbicidal activity tested with three different weeds.
\end{abstract}

\section{INTRODUCTION}

We have reported previously that benzoxazine derivatives are a new chemical family of diphenyl ether herbicides, which exhibit a strong herbicidal activity against mono- and dicotyledonous species. ${ }^{1)}$ Their peroxidizing activity has not convincingly been determined as yet, although accumulation of protoporphyrin IX (PPIX) and chlorophyll decrease has been demonstrated with liverwort cells treated with some benzoxazine derivatives. ${ }^{1,2)}$

Light-induced ethane formation in Scenedesmus acutus cultures in the presence of wellknown peroxidizing herbicides, such as oxyfluorfen or chlorophthalim, has been determined as a convenient parameter to assay for peroxidation of new compounds. ${ }^{3-6)}$ Recently, the protoporphyrinogen-IX oxidase (Protox) inhibition by these compounds has been included in the peroxidation assay. ${ }^{7)}$

In this paper, the peroxidizing activity of new diphenyl-ether type herbicides was investigated using Scenedesmus cells and cell-free Protox activity of maize.

\section{MATERIALS AND METHODS}

\section{Chemicals}

\subsection{Oxyfluorfen}

Oxyfluorfen, 2-chloro-4-trifluoromethylphenyl-3-ethoxy4-nitrophenyl ether, was prepared by treating 1,3bis(2-chloro-4-trifluoromethylphenoxy)-4-nitro-benzene with ethanolic $\mathrm{KOH}$, according to the method of Yih \& Swithenbank. ${ }^{8)}$

\subsection{Diphenyl ether compounds}

7-[2-Chloro-6-fluoro-4-(trifluoromethyl)phenoxy]-2, 4-dimethyl-2 $H, 4 H-1$, 4-benzoxazine-3-one (2), was prepared by $N$-methylation of 7-[2-chloro-6-fluoro-4(trifluoromethyl)phenoxy]-2-methyl-2H,4H-1,4-benzoxazine-3-one ${ }^{1)}$ with $\mathrm{NaH}$ in DMF, then with $\mathrm{CH}_{3} \mathrm{I}$.

6-[2-Chloro-6-fluoro-4-(trifluoromethyl)phenoxy]-1propargyl-3, 4-tetrahydroquinoline-2-one (11), was obtained by $N$-alkylation of 6-[2-chloro-6-fluoro-4(trifluoromethyl)phenoxy]-3, 4-tetrahydroquinoline-2one with propargyl bromide. ${ }^{9)}$

6-[2-Chloro-6-fluoro-4-(trifluoromethyl)phenoxy]-1, 3-dimethyl-1 $H, 3 H$-quinazoline-2,4-dione (12), was prepared by $N$-methylation of 6-[2-chloro-6-fluoro-4-(trifluoromethyl)phenoxy]-1 $H, 3 H$-quinazoline-2, 4-dione with $\mathrm{CH}_{3} \mathrm{I}^{10}{ }^{10}$ 
Other test compounds were similarly prepared according to the methods mentioned above.

\subsection{Chemicals for culture and analysis}

Analytical-grade chemicals for algae cultivation and other fine chemicals, such like protoporphyrin IX and buffers, were purchased from Kanto Chemical Co., Inc., Tokyo, or Sigma, München, Germany.

\section{Phytotoxic Assays of Compounds \\ 2.1 Algae cultivation}

The green microalga, S. acutus, was grown autotrophically in sterile liquid culture by gassing air enriched with $4 \%(\mathrm{v} / \mathrm{v})$ of $\mathrm{CO}_{2}$ according to Nicolaus et al. ${ }^{11)}$ The algae were grown for $24 \mathrm{hr}$ at $22^{\circ} \mathrm{C}$ at $80 \mu$ Einstein $\mathrm{m}^{-2} \mathrm{sec}^{-1}$ (about 6000 lux, provided by fluorescent lamps); cultivation started with a cell density of $1 \mu 1$ packed cell volume (pcv) $/ \mathrm{ml}$ algal suspension.

\subsection{Determination of phytotoxic activities using $S$. acutus}

Each test compound dissolved in methanol was applied at the required concentration to a $24-\mathrm{hr}$ algae cell suspension with a density of $2 \mu 1 \mathrm{pcv} / \mathrm{ml}$ of cell suspension. The final methanol concentration did not exceed 0.1\%. Experiments were performed in gas-tight 9-ml vials. Two milliliters of algae suspension containing 5 $\mathrm{mM} \mathrm{NaHCO}{ }_{3}$ was shaken in a Warburg apparatus for 16 hr at $22^{\circ} \mathrm{C}$ in the light at 17,000 lux. After incubation, cell growth, chlorophyll content and ethane formation were determined according to our methods. ${ }^{4,6,11,12)}$ Cell growth was expressed as $\mathrm{pcv} / \mathrm{ml}$ of the algae culture volume. Total chlorophyll content was determined spectroscopically in a methanolic extract. Ethane was measured by gas chromatography. The $\mathrm{pI}_{50}(\mathrm{Chl})$ of chlorophyll decrease, the negative logarithm of the molar $I_{50}$ value, was used to quantitate the influence of the compound on chlorophyll content. The $\mathrm{pI}_{50}$ (Ethane) was estimated from $I_{50}$ (Ethane), the molar concentration which gives half of the hypothetical maximum of lightinduced ethane formation by autotrophic Scenedesmus.

\subsection{Measurement of protoporphyrinogen-IX oxidase} (Protox) inhibition, pI $_{50}$ (Protox)

Protox inhibition was determined according to the method of Nicolaus et al. ${ }^{11)}$ Maize (Zea mays cv. Anjou) was grown for 6 days in the dark at $30^{\circ} \mathrm{C}$. Seedlings were harvested after exposure for $2 \mathrm{hr}$ to the light. After homogenization, purified plastids which contained Protox were prepared by three differential centrifugation steps. Protox activity was measured by formation of protoporphyrin IX. Protox inhibition was determined after adding compounds to be tested to $3 \mathrm{ml}$ of assay mixture containing $0.1 \mathrm{M}$ Tris- $\mathrm{HCl}^{*}(\mathrm{pH} 7.3), 1$ mM EDTA, 5 mM dithiothreitol (DTT), 0.03\% Tween 80 $(\mathrm{w} / \mathrm{v}), \quad 0.3-0.6 \mathrm{mg}$ of etioplast protein and $2-5 \mu \mathrm{M}$

\footnotetext{
* Abbreviation : Tris, Tris(hydroxymethyl)aminomethane
}

protoporphyrinogen-IX. The amount of PPIX formed was determined for $5 \mathrm{~min}$ by a Hitachi F 2000 fluorescence spectrophotometer, using an excitation and emission wavelength of 405 and $632 \mathrm{~nm}$, respectively. The $I_{50}$ (Protox) value was calculated by the reciprocal plot of PPIX formation in percent of control $v s$. inhibitor concentration (Dixon plots). The $\mathrm{pI}_{50}$ (Protox) value was estimated from $I_{50}$ (Protox), the molar concentration which gives half inhibition of Protox.

\section{Measurement of Herbicidal Activity}

The pre- and postemergent activities under upland conditions were evaluated in the greenhouse. The test species included crabgrass (Digitaria adscendens), common purslane (Portulaca oleracea) and smartweed (Polygonum logistetum). An emulsifiable concentrate was prepared by mixing 15 parts of the compound, 65 parts of xylene and 20 parts of polyoxyethylene alkylaryl ether $(w / w)$. The herbicidal activity of the compound was determined by visible evaluation of the plants in comparison with untreated controls, i.e. 5 : completely killed, $\sim 0:$ no herbicidal effect.

\subsection{Preemergent tests}

Seeds of crabgrass, purslane and smartweed were planted in a seedlings case $(6 \times 15 \times 10 \mathrm{~cm})$ packed with upland field soil. On the day of seeding, a designed amount of the test compound formulated as an emulsifiable concentrate was diluted with water, and then applied to the surface of the soil. Two weeks after application the herbicidal activity score was determined by visual assessment.

\subsection{Postemergent tests}

Seeds of them were planted in a seedlings packed with upland field soil. After a 10-day cultivation in the greenhouse, a designed amount of the test compound was applied to foliage. Two weeks after treatment the herbicidal activity was determined.

\section{RESULTS}

\section{Structure and Activity}

\subsection{Protox inhibition ( $\mathrm{I}_{50}$ (Protox))}

Compound 2, having a benzoxazine ring in place of moiety B of the reference peroxidizer oxyfluorfen (Fig. 1), showed a 10 times less Protox inhibition than oxyfluorfen (Table 1). Although introduction of a fluorine atom (4) at 6 '-position of moiety $A$ of compound 2 resulted in almost the same degree of Protox inhibition as

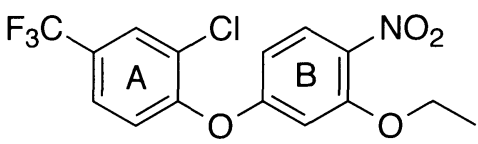

Fig. 1 Structure of oxyfluorfen.

Two benzene rings of oxyfluorfen were distinguished as $\mathrm{A}$ and $\mathrm{B}$ rings. 
Table 1 Phytotoxic activity of new diphenyl ethers type compounds.

\begin{tabular}{|c|c|c|c|c|c|c|}
\hline & \multirow{2}{*}{ Compounds } & \multirow{2}{*}{$\mathrm{mp}\left({ }^{\circ} \mathrm{C}\right)$} & \multicolumn{3}{|c|}{$\mathrm{pl}_{50}$} & \multirow{2}{*}{ References } \\
\hline & & & Chlorophyll & Ethane & Protox & \\
\hline Oxyfluorfen & & $84.0-85.0$ & 6.60 & 6.49 & 8.10 & 8) \\
\hline (2) & & $81.0-84.0$ & 6.21 & 5.64 & 7.21 & 1), 14) \\
\hline (3) & & $80.0-81.5$ & 6.39 & 6.04 & 7.55 & 1), 14) \\
\hline (4) & & $62.0-64.0$ & 6.87 & 6.98 & 7.96 & 1), 14) \\
\hline (5) & & $81.5-83.5$ & $<5.00$ & $<5.00$ & 7.28 & 1), 14) \\
\hline (6) & & $162.0-163.0$ & 6.10 & 5.41 & 7.96 & 1), 14) \\
\hline (7) & & $105.0-105.5$ & 6.64 & 6.25 & 8.06 & 13) \\
\hline (8) & & $58.0-60.0$ & 6.78 & 6.98 & 8.64 & 13) \\
\hline (9) & & Oil & 5.75 & 6.12 & 8.10 & 13) \\
\hline (10) & & $154.5-156.5$ & 6.07 & 6.02 & 7.00 & 9) \\
\hline (11) & & $124.6-126.8$ & 6.89 & 7.07 & 7.92 & 9) \\
\hline (12) & & $154.0-155.5$ & 5.77 & 5.13 & 7.62 & 1) \\
\hline
\end{tabular}

oxyfluorfen, introduction of chlorine (3) at 6'-position exhibited an intermediate inhibition between compounds 2 and oxyfluorfen. The thiono-derivative (5) was 5 times less active than compound 4 . Introduction of a carboxyl-, ether- or oxime-group (6, 7 and 9 , respectively) at 2-position of the benzoxazine ring of compound 4 did not change the strong Protox inhibition activity of compound 4 , while introduction of an amide group (8) at 2-position brought a remarkably high Protox inhibition ( 5 times stronger inhibition than compound 4). Compounds 6 to 9 were all quite active $(6: 7.96,7: 8.06,8$ : 8.64 and $9: 8.10$, respectively).

Replacement of the benzoxazine moiety of compound 4 by a quinoline ring (11) did not change the activity, but the $2^{\prime}$-chloro analog (10) of compound 11 was 10 times less active than compound 4. Compound 12 with a replacement of the benzoxazine ring by a quinazoline was twice less active than compound 4.

\subsection{Ethane formation and chlorophyll decrease}

Ethane formation ( $\mathrm{pI}_{50}$ (Ethane)) and chlorophyll decrease $\left(\mathrm{pI}_{50}(\mathrm{Chl})\right)$ by diphenyl ether compounds tested with $S$. acutus are also shown in Table 1 . For both ethane formation and bleaching by compounds 2,3 and 4 , carrying a benzoxazine ring in place of moiety $B$ of the reference peroxidizer oxyfluorfen, the order was as follows; peroxidative ethane formation, (4) $>(3)>(2)$, and chlorophyll decrease, (4) $>(3)>(2)$. Compound 5 was extremely weak, although it exhibited almost the same level of Protox inhibition as compound 4. An amide group (8) at 2-position of the benzoxazine ring of com- 
pound 4 resulted in almost the same activity for ethane formation and chlorophyll decrease as compound 4 . Introduction of a carboxy- (6), ester- (7), and oximegroup (9) at 2-position generally decreased peroxidizing and bleaching effects. Replacement of the benzoxazine part of compound 4 for a quinoline ring (11) did not change the peroxidizing and bleaching activities, while the $2^{\prime}$-chloro analog (10) was about 10 times less active than compound 4. Replacement of the benzoxazine part by a quinazoline ring (12) resulted in about 10 times less activity compared to compound 4 .

\section{Herbicidal Activity}

Herbicidal activities were evaluated using crabgrass (D. adscendens), common purslane $(P$. oleracea $)$ and smartweed $(P$. logistetum $)$. Pre- and post-emergence herbicidal activities gave similar results and the series of benzoxazine, benzoquinoline and benzoquinazoline derivatives were more active on dicotyledonous than monocotyledonous species (Table 2). The order of herbicidal activity of benzoxazine compounds were as follows; (4) $>$ (5) $>$ (2) $>$ (3). Benzoxazine derivatives with a carboxy-(6), ester- (7), amide- (8) and oximegroup (9) at 2-position showed relatively strong herbicidal activity. Especially, compound (8) exhibited strong herbicidal activity to both dicotyledonous and monocotyledonous species. When the benzoxazine part was replaced by a quinoline ring (10 and 11), the herbicidal activity of compound $\mathbf{1 1}$ was less active than compound 10, although compound 11 was a rather strong inhibitor of Protox and peroxidizer. Exchanging the benzoxazine ring for quinazoline decreased herbicidal activity.

\section{DISCUSSION}

The first effect of the $p$-nitrophenyl ethers and cyclic imides, typical representatives of so-called peroxidizing herbicides, is a halt of chlorophyll biosynthesis in chloroplasts. $^{7)}$ This inhibition is accompanied by an abnormal accumulation of protoporphyrin IX which functions in the light as a photosensitizer and induces radical reactions with subsequent destruction of thylakoid membranes, followed by degradation of cellular constituents like photosynthetic pigments. Four phytotoxic parameters, namely Protox inhibition $\left(\mathrm{pI}_{50}\right.$ (Protox)), protoporphyrin IX accumulation, ethane formation $\left(\mathrm{pI}_{50}\right.$ (Ethane)) and decrease of chlorophyll content $\left(\mathrm{pI}_{50}(\mathrm{Chl})\right)$, can be used conveniently to assay peroxidative activity of the compounds with autotrophic Scenedesmus cells.5) These parameters indicate inhibition of chlorophyll biosynthesis, peroxidative destruction of cell membranes induced by light-mediated radical reactions combined with a bleaching effect through chlorophyll deficiency. The effect of benzoxazine, benzoquinoline and benzoquinazoline compounds on protoporphyrin IX accumulation, ethane formation, decrease of chlorophyll content and cell growth in Scenedesmus cells were quite similar to those caused by the reference peroxidizing herbicide, oxyfluorfen. According to these findings, all the benzoxazines and benzoquinolines and benzoquinazoline compounds tested are now confirmed as peroxidizing herbicides, although strength of their activity differs.

Furthermore, we have synthesized strong Protox inhibitors by introducing benzoxazine, benzoquinoline or benzoquinazoline rings to the diphenyl ether, and by

Table 2 Herbicidal activity of new diphenyl ethers type compounds.

\begin{tabular}{|c|c|c|c|c|c|c|}
\hline \multirow{2}{*}{ Compounds } & \multicolumn{3}{|c|}{$\operatorname{Pre}(5 \mathrm{~g} /$ a.i. $)$} & \multicolumn{3}{|c|}{ Post ( $5 \mathrm{~g} /$ a.i. $)$} \\
\hline & D. adscendens & P. oleracea & P. logistetum & D. adscendens & P. oleracea & P. logistetum \\
\hline Oxyfluorfen & $\begin{array}{r}5 \\
(1\end{array}$ & $\begin{array}{l}3 \\
1\end{array}$ & $\begin{array}{l}5 \\
1\end{array}$ & $\begin{array}{l}2 \\
0\end{array}$ & $\begin{array}{l}5 \\
4\end{array}$ & $\begin{array}{l}5 \\
3)\end{array}$ \\
\hline (2) & 2 & 2.5 & 2.5 & 2.5 & 5 & 4.5 \\
\hline (3) & 0 & 2 & 0 & 0 & 3 & 1.5 \\
\hline (4) & $\begin{array}{c}5 \\
(4.5\end{array}$ & $\begin{array}{l}5 \\
4.5\end{array}$ & $\begin{array}{l}5 \\
3.5\end{array}$ & $\begin{array}{l}5 \\
4.5\end{array}$ & $\begin{array}{l}5 \\
5\end{array}$ & $\begin{array}{l}5 \\
5)\end{array}$ \\
\hline (5) & 2.5 & 5 & 5 & 3 & 5 & 5 \\
\hline (6) & 4.5 & 5 & 5 & 5 & 5 & 5 \\
\hline (7) & 3 & 3 & 2.5 & 1.5 & 5 & 5 \\
\hline (8) & 5 & 5 & 5 & 4.5 & 5 & 5 \\
\hline (9) & $\left(^{1.5}\right.$ & $\begin{array}{l}5 \\
4\end{array}$ & $\begin{array}{l}3 \\
1.5\end{array}$ & $\begin{array}{l}2 \\
1.5\end{array}$ & $\begin{array}{l}5 \\
5\end{array}$ & $\begin{array}{l}5 \\
5)\end{array}$ \\
\hline (10) & $\begin{array}{l}4.5 \\
(2\end{array}$ & $\begin{array}{l}5 \\
4\end{array}$ & $\begin{array}{l}5 \\
3.5\end{array}$ & $\begin{array}{l}5 \\
2\end{array}$ & $\begin{array}{l}5 \\
5\end{array}$ & $\begin{array}{l}5 \\
5)\end{array}$ \\
\hline (11) & $\begin{array}{r}2.5 \\
(1.5\end{array}$ & $\begin{array}{l}5 \\
2\end{array}$ & $\begin{array}{l}3 \\
2\end{array}$ & $\begin{array}{l}1.5 \\
1\end{array}$ & $\begin{array}{l}5 \\
5\end{array}$ & $\begin{array}{l}5 \\
2.5)\end{array}$ \\
\hline (12) & 0 & 1.5 & 0 & 1 & 4 & 2.5 \\
\hline
\end{tabular}

Data in parentheses : $1.25 \mathrm{~g} /$ a.i. The herbicidal activity of the compound was determined by visible evaluation of the treated plants in comparison with controls $(5=$ completely killed, $0=$ no herbicidal effect $)$. 
adding fluorine but not chlorine at the 2 -position of the diphenyl ether moiety. The selected compounds 4,8 and 11 strongly inhibited Protox and also resulted in strong membrane destruction, i.e. peroxidizing activity (Table 1). A compound showing a strong membrane destruction activity also was a strong inhibitor of Protox activity. Furthermore, ether- (7), amide- (8) or oxime-group (9) introduced at 2-position of the benzoxazine ring of compound 4 had a better Protox inhibition and membrane destruction activity. Compound 7 which is the ethyl ester of compound 6 and showed similarly high Protox inhibition activity, was a more active peroxidizer than compound 6 . A superior peroxidizing activity of the esters has been also observed with acifluorfen methyl and acifluorfen. ${ }^{15)}$

Previously we have reported that the series of benzoxazine derivatives showed strong herbicidal activity (more active on dicotyledonous than monocotyledonous species) and caused protoporphyrin IX accumulation in liverwort cells. ${ }^{1)} \quad$ Benzoxazine derivatives (compounds 2 to 9) and the benzoquinazoline compound $\mathbf{1 2}$ gave a good correlation between herbicidal activity and phytotoxic parameters ( $\mathrm{pI}_{50}$ (Protox), $\mathrm{pI}_{50}$ (Ethane) and $\mathrm{pI}_{50}(\mathrm{Chl})$ ), except compounds 5,6 and 7. Compound 5 is the thiono-derivative of compound 4 (Table 2). Although compound $\mathbf{5}$ had a weak peroxidizing activity but a comparatively strong Protox inhibition activity, it showed a strong herbicidal effect. We assume that compound 5 is converted to compound $\mathbf{4}$, with strong herbicidal activity against both mono- and dicotyledonous species, considering that chlorthiamid (2,6-dichlorobenzthioamide) is metabolized to herbicidal 2,6dichlorobenzamide via dichlobenil (2,6-dichlorobenzonitrile) in plant and soil. ${ }^{16)}$ Benzoquinoline compound 10 was a weak but compound 11 a strong peroxidizer, on other hand herbicidal activity of compound $\mathbf{1 0}$ was strong but compound $\mathbf{1 1}$ was weak. Compounds $\mathbf{6}$, 7, 10 and 11 did not exhibit a good correlation between herbicidal activity and phytotoxic parameters. This fact may be due to their metabolism or translocation in plant.

The benzoxazine, benzoquinoline and benzoquinazoline herbicides presented here, having a chemical structure without a nitro group, showed the same symptoms with whole plants and three typical phytotoxic parameters. They have the same mode of action as $p$-nitrodiphenyl ether herbicides.

\section{REFERENCES}

1) M. Sumida, S. Niwata, H. Fukami, T. Tanaka, K. Wakabayashi \& P. Böer : J. Agric. Food Chem. 43, 1929 (1995)

2) M. Sumida, S. Niwata, S. Iwata, T. Tanaka, K. Wakabayashi \& P. Böger : "Pesticides/Environment ; Molecular Biological Approaches," ed. by T. Mitsui, F. Matsumura \& I. Yamaguchi, Pestic. Sci. Soc. Jpn., Tokyo, pp. 255-262, 1993

3) C. Ogino, T. Hoshi, T. Iida, S. Koura, H. Kohno, Y. Sato, M. Takai \& K. Wakabayashi : J. Pesticide Sci. 18, 369
(1993)

4) K. Wakabayashi, G. Sandmann, H. Ohta \& P. Böger: $J$. Pesticide Sci. 13, 461 (1988)

5) H. Watanabe, Y. Ohori, G. Sandmann, K. Wakabayashi \& P. Böger : Pestic. Biochem. Physiol. 42, 99 (1992)

6) H. Kohno, C. Ogino, T. Iida, S. Takasuka, Y. Sato, B. Nicolaus, P. Böger \& K. Wakabayashi : J. Pesticide Sci. 20, 137 (1995)

7) K. Wakabayashi \& P. Böger: "Pesticides/Environment ; Molecular Biological Approaches," ed. by T. Mitsui, F. Matsumura \& I. Yamaguchi, Pestic. Sci. Soc. Jpn., Tokyo, pp. 239-253, 1993

8) R. H. Yih \& C. Swithenbank : J. Agric. Food Chem. 23, 592 (1975)

9) K. Sakagami, H. Fukami, N. Kawaguchi, S. Niwata, R. Sago \& K. Igai (Suntory, Ltd.) : Jpn. Kokai Tokkyo Koho JP 5-339239 (1993)

10) H. Fukami, M. Sumida, S. Niwata, T. Tanaka \& K. Igai : Abstr.; 19th Pestic. Sci. Soc. Jpn., A129, 1994 (abstract in Japanese)

11) B. Nicolaus, G. Sandmann \& P. Böger : "Target Assay for Modern Herbicides and Related Phytotoxic Compounds," ed. by P. Böger \& G. Sandmann, Lewis Publ., Boca Raton, FL, U.S.A., pp. 34-41, 1993

12) H. Watanabe, G. Sandmann, K. Wakabayashi \& P. Böger : "Target Assays for Modern Herbicides and Related Phytotoxic Compounds," ed. by P. Böger \& G. Sandmann, Lewis Publ., Boca Raton, FL, U.S.A., pp. 43-49, 1993

13) N. Kawaguchi, H. Fukami, R. Sago \& K. Igai (Suntory, Ltd.) : Jpn. Kokai Tokkyo Koho JP 5-4977 (1993)

14) N. Kawaguchi, H. Fukami, S. Niwata, R. Sago \& F. Fujita (Suntory, Ltd.) : Jpn. Kokai Tokkyo Koho JP 6-316568 (1994)

15) B. Nicolaus, J. N. Johansen \& P. Böger : Pestic. Biochem. Physiol. 51, 20 (1995)

16) D. S. Frear: "Herbicides; Chemistry Degradation, and Mode of Action," ed. by P. C. Kearney \& D. Kaufman, Marcel Dekker, Inc., New York/Basel, pp. 542-607, 1976

\section{要 約 \\ 新規ジフェニルエーテル系化合物の Protoporphyri- nogen-IX Oxidase 阻害}

角田元男，河野 均，正田 航，深見治一

田中隆治, 若林 攻, Peter BÖGER

11 種のベンゾオキサジン, ベンゾキノリンおよびベンゾ キナゾリン誘導体を合成し, それらの植物毒性をScenedesmus acutus を用いて検討した.これらの化合物は既知の peroxidizing 除草剂と同様に, 光照射下で Scenedesmus の生育 を阻害し,クロロフィル含量を減少させ, ProtoporphyrinogenIX oxidase を阻害し, エタンを発生した. 以上の結果から, これら化合物群は peroxidizing 作用で除草活性を示すこと が判明した.すなわち,これら化合物群はクロロフィル生合 成系の Protoporphyrinogen-IX oxidase を阻害し，その結 果, 蓄積する物質が関与して生じる酸素ラジカルによって チラコイド膜が破壊されてエタンを発生する作用機構をも つものと考之られた．さらにこれら化合物の除草活性を調 べた結果, Scenedesmusにおける植物毒性のパラメーター とこの除草活性との間には高い相関が認められた。 